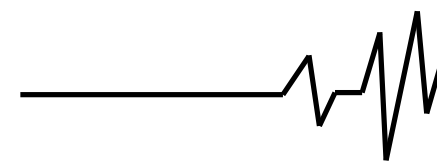

Sereda L.

Ph.D., Professor

Trukhanska 0.

Ph.D., Associate Professor

Shvets $\mathbf{L}$.

Ph.D., Associate Professor

Vinnytsia National Agrarian University

\section{INVESTIGATION OF THE HYDRAULIC DRIVE OF THE UNIT FOR STRIP TILLAGE WITH SIMULTANEOUS APPLICATION OF LIQUID FERTILIZERS}

One of the most difficult issues at present is the land market. In the political direction, there is an extensive discussion about the land market, but almost no one raises the issue of its preservation for future generations. Many scientists, especially soil scientists, warn of the gradual loss of its fertile potential due to a sharp decrease in the soil of the main indicator fertility humus. As a result of conducting intensive technologies in crop production in the agro-industrial complex, the main purpose of which is to obtain large profits, the recommended crop rotations are not followed, as crops such as wheat, corn, soybeans and sunflowers are grown.

With this attitude to the land, it will lose fertility in the near future, due to a sharp drop in humus. In many publications of soil scientists over the past 20 years, humus has decreased by almost $2 \%$ on average, while in the previous 100 years it has decreased by $1.5-2 \%$.

Thus, it is urgent to change the adopted technology to soil-preserving, which, along with the preservation of the soil with their proper implementation are not inferior to the yield of industrial technologies.

It is necessary to pay attention to how energy and soilsaving technologies are used in most countries of America, Canada, and Europe. These are No-Till and Strip-till technologies. These technologies are based on minimal tillage with mandatory high-quality soil cover with crop residues. The technology is complex and requires proper implementation in the presence of appropriate machines.

In Vinnytsia National Agrarian University has developed a design of units most accessible to farms Strip-till strip tillage technologies.

Keywords: technologies, No-till, Strip-till, unit, strip tillage, soil, liquid fertilizers, hydraulic drive, efficiency.
Introduction. Taking into account the properties of land conservation as the main wealth of Ukraine, it is advisable in the near future to thoroughly implement soil-preserving technologies, while ensuring the necessary crop yields. To do this, it is necessary to concentrate the necessary training in agricultural bulk institutions, as well as to involve research facilities and the engineering industry [1, 2].

In Vinnytsia National Agrarian University has developed a milling cultivator design based on a well-known design cultivator KFGG - 3,6. The purpose of the development was to replace the continuous cooperation created on the strip works, in accordance with Strip-till technologies. Six milling drums offered employees $30 \mathrm{~cm}$ wide strips, the row spacing also remains $30 \mathrm{~cm}$. But the main advantage of the new unit was the replacement of the bulky mechanical input with a hydraulic one for the introduction of milling drums [3].

The development of a complex unit as a part of a large-volume tank for liquid organic fertilizers, introduction through a spray on a strip with the subsequent processing by a milling cultivator is currently being completed.

Analysis of recent research and publications. When reviewing the publications, it 


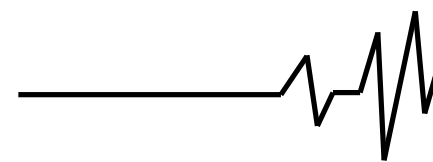

was taken into account that along with Strip-till technology, publications [2,4] in the field of hydraulic drive of working units of agricultural units for strip tillage, as well as preparation and application of liquid organic fertilizers were also considered. Thus, German scientists made a significant contribution to the development of the working bodies of milling cultivators $[8,9]$. They mathematically proved the superiority of milling tillage, and proposed efficient working bodies.

Ukrainian scientists have theoretically substantiated the shape of milling L-shaped knives $[4,5]$.

Thus, as a result of recent studies of hydraulic drive of working bodies, it is established that many works are devoted to hydraulic drive of self-propelled machines, based on hydraulic transmissions produced by Ukrainian manufacturers (Kropyvnytskyi). Leading scientists have created an effective hydraulic system for automatic speed control of the reel drum of DON-1500 and Yenisei1200 combine harvesters.

Foreign scientists [7-9] have developed hydrostatic drive systems for self-propelled machines.

\section{Вібрації в техніці та технологіях}

Presenting main material. Currently, the development of a complex unit as part of a mobile installation of large capacity, in the form of a tank and an upgraded cultivator KFGG-3,6. This unit will be used for strip tillage with simultaneous application of liquid organic fertilizers. Why was this option chosen? The fact is that a number of biogas plants have been built in the region that process waste, especially chickens.

Only in the largest poultry farm in Europe Ladyzhyn, chicken waste is more than 20 thousand tons per day. The biogas plant, which will come into operation, will convert this mass into biogas. Given that a ton of chicken manure requires about 30 tons of water, large accumulators of liquid waste will be spared, which can be good liquid organic fertilizers.

Thus, fertilizers as a by-product will have a low cost, and it is advisable to develop technology for their collection, transportation and application to the soil $[3,6]$.

The proposed unit, the scheme of which is shown in Fig. 1, consists of two machines: a large tank 1 which is aggregated with a class 4 tractor and a milling modernized cultivator 2 KFGG - 3,6 for strip tillage, which is attached to the tank.

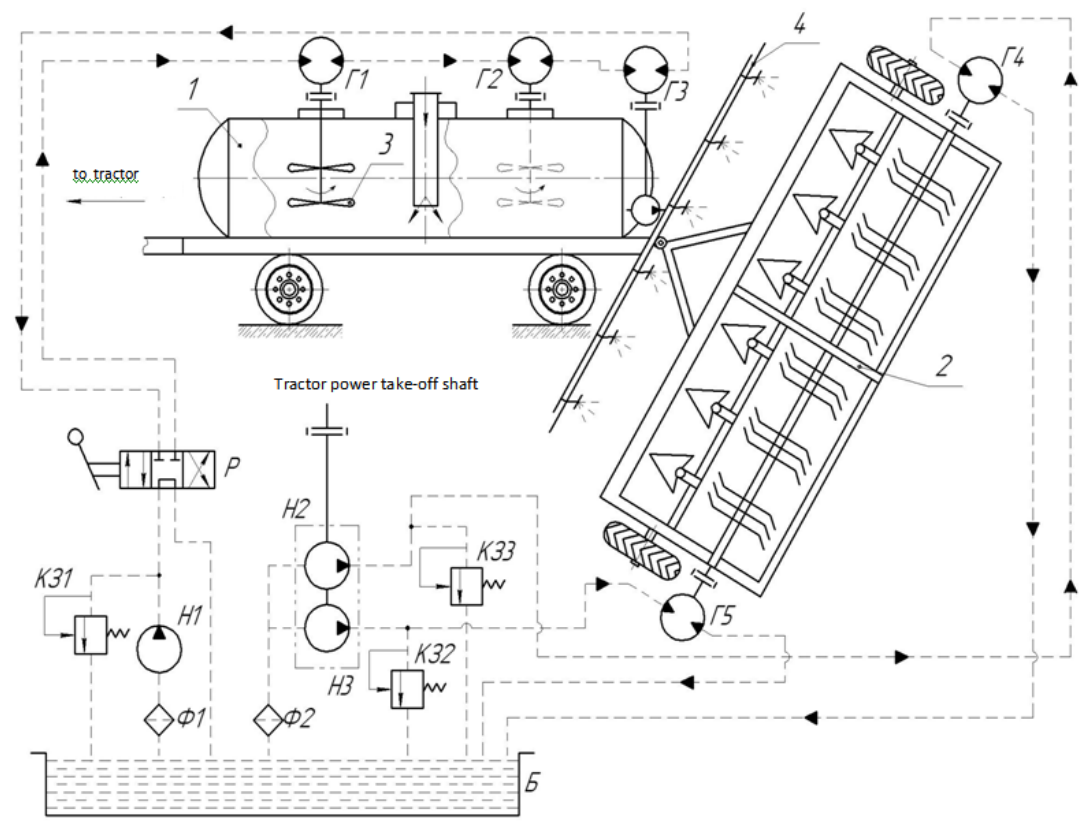

Fig. 1. Scheme of the combined unit

A feature of the design of this unit is that the tank is equipped with two stirrers 3 , which are driven by series-connected hydraulic motors G1 and G2. The need for agitators is the constant mixing of liquid organic fertilizers, in order to provide homogeneity in the application process.

Even application of liquid fertilizer to the strip is ensured by the supply of liquid by a pump driven by a hydraulic motor G3. A special device 4 is mounted on the tank for uniform fertilizer application.
Milling cultivator KFGG - 3,6 has six arrow paws placed in front of six milling drums, with two separate sections. The milling drum processes a strip $30 \mathrm{~cm}$ wide, and between them there is an unprocessed strip in $25-30 \mathrm{~cm}$. Given the high power in tillage, the drive of each section is driven by hightorque hydraulic motors $\mathrm{G} 4$ and $\mathrm{G} 5$.

Given that the basis of this development is the widespread use of hydraulic drive, it is necessary to use for aggregation a class 4 tractor, with 


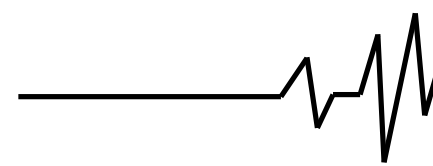

mandatory cooling of the working fluid of the hydraulic system, which has a special radiator.

To supply fluid to the hydraulic motors G1, G2 and G3, use a hydraulic line from the distributor, and hydraulic motors G4 and G5 have a separate system consisting of a pump NSh-10-10U3 which is driven by the GDP shaft of the tractor.

The originality of the development lies in the fact that a hydraulic drive system is used to drive the mixers, with hydraulic motors connected in series, which must be thoroughly investigated in the future.
The study is based on the construction of a mathematical model with series-connected hydraulic motors, which drive two stirrers in the tank. When developing a mathematical model, the following assumptions are made:

The thermal regime of the hydraulic system is set. Losses on friction of hydraulic motors are proportional to speed of turns. Friction and wave processes in hydraulic lines are not taken into account due to their small size. In fig. 2 shows a diagram of hydraulic motors, with a series connection.

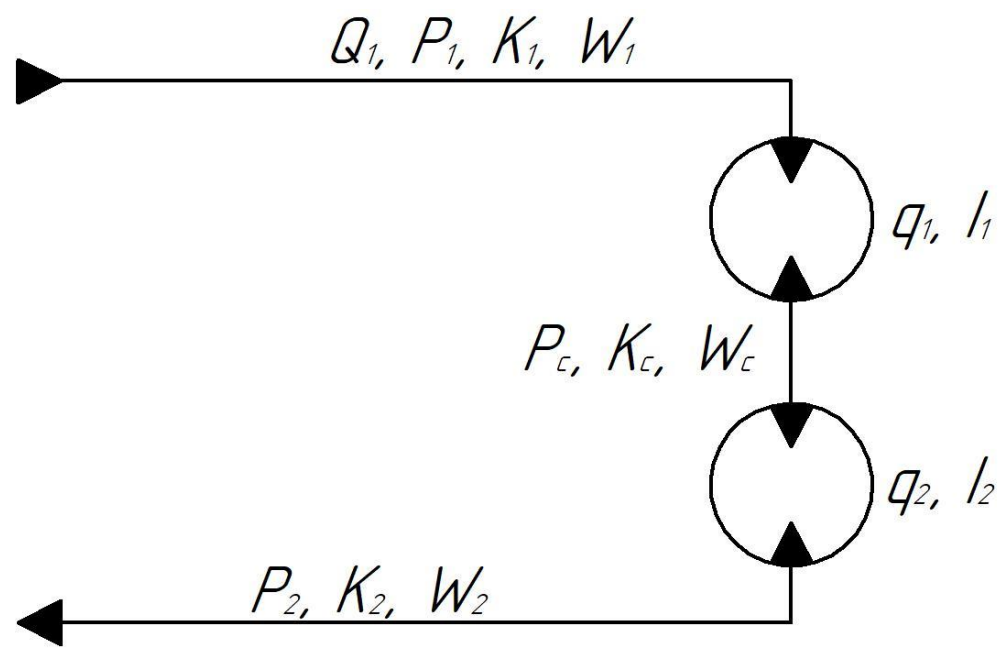

Fig. 2 - Scheme of serial connection of hydraulic motors

According to the scheme, the supply Qn of the running pump in the constant supply mode is fed to the input of the first hydraulic motor with a characteristic volume $q(\varphi 1)$, taking into account the pulsation as a dependence q1 $(\varphi 1)$. The elastic properties of the pipe cavities connecting the pump to the first hydraulic motor are determined by the volume W1 and the coefficient K1 (p1). The moment of inertia on the shaft of the hydraulic motor I1 is given. The pressure at the inlet to the first hydraulic motor P1, and at the inlet to the second hydraulic motor PO. The output of the first hydraulic motor is connected to the second hydraulic line by volume WO, and coefficient Kc (Pc). The characteristic volume of the second hydraulic motor with the moment of inertia on its shaft is equal to q2 $(\varphi 2)$ and 12 , respectively.

The flow rate in the drain line is determined by the value of Q2. The elastic properties of the drain line are characterized by the volume W2 and the coefficient elasticity K2 (P2), taking into account the above assumptions, the dynamic processes in hydraulic systems are described by the following equations:

Equation of continuity of the working fluid flow in the pressure line, connecting the pump to the inlet of the first hydraulic motor [6]:

$$
Q_{1}-q_{1} \cdot\left(\varphi_{1}\right) \cdot \omega_{1}-K_{1} \cdot\left(P_{1}\right) \cdot W_{1} \cdot \frac{d P_{1}}{d t}-\sigma_{1} \cdot\left(\varphi_{1}\right) \cdot p_{1}=0
$$

The equation of continuity of the flow of working fluid in the line between the first and second hydraulic motor [2]:

$$
q_{1}\left(\varphi_{1}\right) \cdot \omega_{1}+q_{2}\left(\varphi_{2}\right) \omega_{2}-K_{c}\left(P_{c}\right) \cdot W_{c} \frac{d P_{c}}{d t}-\delta_{c}\left(\varphi_{1} \cdot \varphi_{2}\right)-\delta_{c}\left(\varphi_{1} \cdot \varphi_{2}\right)-p_{c}(2)
$$

The equation of continuity of flow in the main on the drain from the second hydraulic motor [2]: 


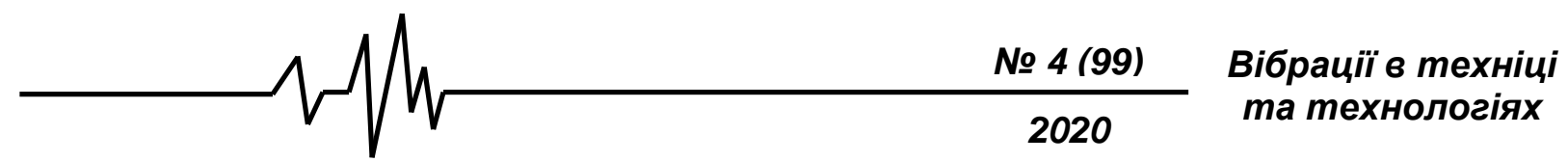

$$
q_{2} \cdot\left(\varphi_{2}\right) \cdot \omega_{2}-K_{2}\left(P_{2}\right) \cdot W_{2} \cdot \frac{d P_{2}}{d t}-\sigma_{2} \cdot\left(\varphi_{2}\right) \cdot p_{2}=0
$$

The equation of torque on the shaft of the

first hydraulic motor is determined by [2]:

$$
q_{1} \cdot\left(\varphi_{1}\right) \cdot\left(P_{1}-P_{\mathrm{c}}\right)=I_{1} \cdot \frac{d \omega_{1}}{d t}+b_{1} \cdot \omega_{1}+M_{T_{1}}+M_{T \mathrm{p}}
$$

Equation of moments on the shaft of the second hydraulic motor [2]:

$$
q_{2} \cdot\left(\varphi_{2}\right) \cdot\left(P_{\mathrm{c}}-P_{2}\right)=I_{2} \cdot \frac{d \omega_{2}}{d t}+b_{2} \cdot \omega_{2}+M_{T_{2}}+M_{T \mathrm{p}_{2}}
$$
accepted:

In equations 1-5 the following notation is $b_{1}, b_{2}-$ coefficients of active resistance in the first and second circuits, including losses in hydraulic motors:

$\omega_{1}, \omega_{2}-$ angular velocities of the first and $M_{\mathrm{T} 1}, M_{\mathrm{T} 2}-$ moments of technological loads of second hydraulic motors; working bodies;

$\delta_{1}\left(\varphi_{1}\right), \delta_{2}\left(\varphi_{2}\right), \delta\left(\varphi_{1}, \varphi_{2}\right)$ - coefficients of $\quad M_{T p 1}, M_{T p 2}-$ moments in hydraulic motors which hydraulic losses from overflows in cavities of theare on equations:

hydraulic drive under pressure $\mathrm{P}_{1}, \mathrm{P}_{2}, \mathrm{P}_{0}$ respectively;

$$
\begin{aligned}
& M_{T P_{1}}=\varepsilon_{1} \cdot\left[P_{1_{\Pi}} \cdot F_{1}+0,5 \cdot \psi_{1} \cdot\left(P_{c}+P_{2}\right)+\xi_{1} \cdot\left(P_{1}+P_{c}\right)\right] \\
& M_{T P_{2}}=\varepsilon_{2} \cdot\left[P_{2_{\Pi}} \cdot F_{2}+0,5 \cdot \psi_{2} \cdot\left(P_{c}+P_{2}\right) \cdot+\xi_{2} \cdot\left(P_{2}+P_{c}\right)\right]
\end{aligned}
$$

$\varepsilon_{1}, \varepsilon_{2}-$ coefficients of friction losses in hydraulic motors;

$F_{1}, F_{2}$ - pressing force of working elements in hydraulic motors;

$\psi_{1}, \psi_{2}$ - areas of pressing parts;

$\xi_{1}, \xi_{2}$ - coefficients of friction losses at rotations of hydraulic drives.

In the analysis of equations (1-5) it is established that the mathematical model of the hydraulic drive with series-connected hydraulic motors at certain parameters and insignificant losses on friction in small highways, taking into account change of volume of liquid at flow from one cavity of the hydraulic motor, in the second is proportional to pressure difference in the hydraulic motor.
Nonlinear losses in the hydraulic motor depend on the angular coordinate $\varphi$, the angular velocity $\omega$ of the rotor, as well as the pressure in the cavities of the hydraulic motor.

A clear nonlinear characteristic of the mathematical model of the hydraulic drive is the characteristic of the moment of friction:

$M_{T p}=M_{T p} \cdot(\varphi, \omega, P)$.

It should be noted that the dependencies $M_{\text {тр }}(\varphi, \omega, P)$ implemented through the use of dependencies $\varepsilon(\varphi, \omega)$ i $\xi(\varphi, \omega)$, as well as expressions of equations (6) and (7) which are the relationship between $M_{T p}$ and pressure in the cavities of hydraulic motors. the form:

The model with accepted conventions has

$$
\begin{gathered}
Q_{1}-\sigma_{1} \cdot\left(P_{1_{0}}+\Delta P_{1}\right) \cdot K_{1} \cdot W_{1} \cdot \frac{d\left(P_{1_{0}}+\Delta P_{1}\right)}{d t}-q_{1} \cdot\left(\omega_{1_{0}}+\Delta \omega_{1}\right)=0 \\
q_{1}\left(\omega_{1_{0}}+\Delta \omega_{1}\right)-\sigma_{c}\left(P_{c_{0}}+\Delta P_{c}\right)-K_{c} \cdot W_{c} \frac{d\left(P_{1_{0}}+\Delta P_{1}\right)}{d t}-q_{2}\left(\omega_{2_{0}}+\Delta \omega_{2}\right)=0 \\
q_{1} \cdot\left[\left(P_{1_{0}}+\Delta P_{1}\right)+\left(P_{c_{0}}+\Delta P_{c}\right)\right]-\epsilon_{1} \cdot\left\{\left(P_{1_{0}}+\Delta P_{1}\right) \cdot F_{1}+0,5 \cdot \Psi_{1} \cdot\left[\left(P_{1_{0}}+\Delta P_{1}\right)+\left(P_{c_{0}}+\Delta P_{c}\right)\right]\right\}-\xi_{1} \\
\cdot\left[\left(P_{1_{0}}+\Delta P_{c}\right)+\left(P_{c_{0}}+\Delta P_{c}\right)\right]-I \cdot \frac{d \omega_{1}}{d t}-\left(b_{1}-K_{F 1}\right) \cdot\left(\omega_{1_{0}}+\Delta \omega\right)-M_{T_{1}}=0
\end{gathered}
$$




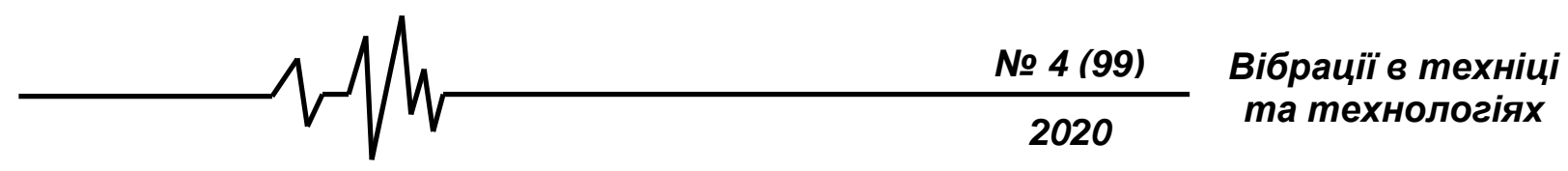

$$
\begin{aligned}
q_{2} \cdot\left[\left(P_{c_{0}}+\Delta P_{c}\right)+\right. & \left.\left(P_{2_{0}}+\Delta P_{2}\right)\right]-\epsilon_{2} \cdot\left\{\left(P_{c_{0}}+\Delta P_{c}\right) \cdot F_{2}-0,5 \cdot \psi_{2} \cdot\left[\left(P_{c_{0}}+\Delta P_{c}\right)+\left(P_{2_{0}}+\Delta P_{2}\right)\right]\right\}-\xi_{2} \\
& {\left[\left(P_{c_{0}}+\Delta P_{c}\right)+\left(P_{2_{0}}+\Delta P_{2}\right)\right]-I_{2} \cdot \frac{d \omega_{2}}{d t}-\left(b_{2}^{p}-K_{F 2}\right) \cdot\left(\omega_{2_{0}}+\Delta \omega_{2}\right)-M_{2}=0 }
\end{aligned}
$$

In equations (10 and 11) the coefficients of active resistance of viscous friction are presented as:

$$
\begin{aligned}
& b_{1}=b_{1}^{I}-K_{F_{1}} \\
& b_{2}=b_{2}^{I}-K_{F_{2}}
\end{aligned}
$$

$\mathrm{b}_{1}{ }^{\prime}, \mathrm{b}_{2}$ - components of viscous friction;

$\mathrm{K}_{\mathrm{F} 1}, \mathrm{~K}_{\mathrm{F} 2}$ - angular coefficients of friction change characteristics.

\section{Conclusions:}

1. When selecting hydraulic motors connected in series from one pump, it is necessary to choose the first hydraulic motor with a smaller volume and higher speed.

2. At the same frequencies, their working volumes depend on the technological loads, taking into account friction losses.

3. It is recommended to use hydraulic motors with a high value of efficiency, and a stable mode of operation at low speeds.

\section{References}

1. Kaletnik G.M., Goncharuk I.V., Yemchyk T.V., Lutkovskaya S.M. (2020) Agrarian policy and land relations. Monographs published in Ukraine Vinnytsia: VNAU. 307 p. [in Ukrainian].

2. Veselovskaya N.R., Ivanov M.I., Rutkevich V.S., Shargorodsky S.A. (2019). Hydraulics: Textbook. Vinnytsia. 222 p. [in Ukrainian].

3. Sereda L.P., Trukhanskaya O.O., Shvets L.V. (2019). Development and research of a tillage machine for strip-till technology with active milling working bodies. All-Ukrainian scientific and technical journal "Vibrations in Engineering and Technology". Vinnytsia, V. 4 (95). [in Ukrainian].

4. Sereda L.P. Zinev M.V. Rutkevich V.S. (2012). Patent of Ukraine №68309 "Mobile biogas plant", publ. March 26, 2012, Bulletin №8. [in Ukrainian].

5. Sereda L.P., Zinev M.V., Rutkevich V.S. (2012). Patent of Ukraine UA68310 "Blade mixer", pub. information 28.03.2012, Bull №5. [in Ukrainian].

6. Shvets L.V., Paladiychuk Y.B., Trukhanskaya O.O. (2019). Technical service in agro-industrial complex. Tom I. Textbook. Vinnytsia National Agrarian University. 647p. [in Ukrainian].

$$
\text { 7. Erns Kasten. }
$$

Entwicreunqstendenzen in der Zucrerrubenezte 2013, №13 c. 353-365. [in Germany].
8. Keener O. (2001) Hydrostatic her Antrieble fur Robensetere machine Aqzatechn int №, 2001-7-10 c. [in Germany].

9. Kogan I. (2012) On the durability analysis if machinery comprents In. Factice Votes №1-7-70 c. [in English].

\section{ДОСЛІДЖЕННЯ ГІДРОПРИВОДУ АГРЕГАТУ ДЛЯ СМУГОВОГО ОБРОБІТКУ ГРУНТУ 3 ОДНОЧАСНИМ ВНЕСЕННЯМ РІДКИХ ДОБРИВ}

Одним із самих складних питань на даний час $€$ питання ринку землі. В політичному напрямку ведеться обширна дискусія про ринок землі, але майже ніхто не піднімає питання ії збереження для майбутніх поколінь. Багато вчених особливо ґрунтознавців попереджують, про поступову втрату їі родючого потенціалу, у зв'язку різкого зменшення в ґрунтах основного показника

родючості - гумусу. В результаті ведення в агропромисловому комплексі інтенсивних технологій в рослинництві, основною ціллю якою $€$ отримання великих прибутків не притримуються рекомендованих сівозмін, так як вирощують такі культури як пшениця, кукурудза, соя та соняшник.

При такому відношенні до землі, вона в недалекому майбутньому втратить родючість, ізза різкого падіння гумусу. В багатьох публікаціях вчених ґрунтознавців за останніх 20 років гумус в середньому понизився майже на $2 \%$, в той час як за 100 попередніх років він зменшився на 1,5-2\%.

Таким чином, терміново потрібно міняти прийняту технологію на ґрунтозберігаючі, які поряд збереженням ґрунту при грамотному їх впровадженні не поступаються урожайністю перед промисловими технологіями.

Потрібно звернути увагу, на те як в більшості, країни Америки, Канади, а також Європи застосовують енерго- та ґрунтозберігаючі технології. Це технології No-Till та Strip-till.

В основу цих технологій закладено мінімальний обробіток ґрунту 3 обов'язковим якісним покривом ґрунту рослинними залишками. Технологія складна i потребує грамотного впровадження при наявності відповідних машин.

На кафредрі агроінженерії та технічному сервісі, розроблено технології і відповідні конструкції агрегатів найбільш доступної для господарств

технології смугового обробітку ґрунту Strip-till.

Ключові слова: технологія No-till ma Strip-till, агрегат для смугового обробітку 


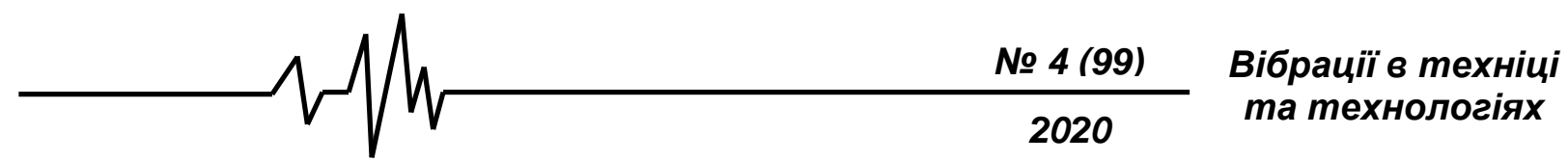

грунту, агрегат для внесення рідких добрив, гідравлічний привід робочих органів 3 послідовним з'єднанням гідромашин, математична модель приводу, ефрективність розробок.

\section{ИССЛЕДОВАНИЕ ГИДРОПРИВОДА АГРЕГАТА ДЛЯ ПОЛОСНОЙ ОБРАБОТКИ ПОЧВЫ С ОДНОВРЕМЕННЫМ ВНЕСЕНИЕМ ЖИДКИХ УДОБРЕНИЙ}

\footnotetext{
Одним из самых сложных вопросов в настоящее время вопрос рынка земли. В политическом направлении ведется обширная дискуссия о рынке земли, но почти никто не поднимает вопрос ее сохранения для будущих поколений. Многие ученые особенно почвоведы предупреждают, о постепенной потере ее плодородного потенциала, в связи с резким уменьшением в почвах основного показателя плодородия - гумуса. В результате внедрения в агропромышленный комплекс интенсивных технологий в растениеводстве, основной целью которой является получение большой прибыли не придерживаются рекомендованных агротребований по выращиванию сельскохозяйственных культур.

При таком отношении к земле, она в скором будущем потеряет плодородие, из-за
}

резкого падения гумуса. Во многих публикациях ученых за последние 20 лет гумус в среднем понизился почти на 2\%, в то время как за 100 предыдущих лет он уменьшился на 1,5-2\%.

Нужно обратить внимание, на то как в большинстве, страны Америки, Канады, а также Европы применяют энерго- и почвосберегающие технологии. Это технологии No-Till и Strip-till.

В основу этих технологий заложено минимальная обработка почвы с обязательным качественным покровом почвы растительными остатками. Технология сложная и требует грамотного внедрения при наличии соответствующих машин.

Нa инженерно-технологическом факультете Винницкого национального аграрного университета разработаны технологии и соответствующие конструкции агрегатов наиболее доступные для хозяйств технологии полосового обработки Strip-till.

Ключевые слова: технология No-till u Strip-till, агрегат для полосового обработки, агрегат для внесения жидких удобрений, гидравлический привод рабочих органов с последовательным соединением гидромашин, математическая модель привода, эфрфективность разработок.

\section{Відомості про авторів}

Sereda Leonid - PhD, Professor, Department of Agricultural Engineering and Technical Service Vinnytsia National Agrarian University (Sunny str., 3, Vinnytsia, Ukraine, 21008, e-mail: leonidsereda@vsau.vin.ua). Trukhanska Elena - PhD, Associate Professor, Department of Agricultural Engineering and Technical Service Vinnytsia National Agrarian University (Sunny str., 3, Vinnytsia, Ukraine, 21008, e-mail: seaswallow@ukr.net).

Shvets Ludmila - PhD, Associate Professor, Department of Agricultural Engineering and Technical Service Vinnytsia National Agrarian University (Sunny str., 3, Vinnytsia, Ukraine, 21008, e-mail: shlv0505@i.ua)

Середа Леонід Павлович - кандидат технічних наук, професор кафредри агроінженерії і технічного сервісу Вінницького національного аграрного університету (ВНАУ, вул. Сонячна, 3, м. Вінниця, Україна, 21008, e-mail: leonidsereda@vsau.vin.ua).

Труханська Олена Олександрівна - кандидат технічних наук, доцент кафедри агроінженерії i технічного сервісу Вінницького національного аграрного університету (ВНАУ, вул. Сонячна, 3, м. Вінниця, Україна, 21008, e-mail: seaswallow@ukr.net).

Швець Людмила Василівна - кандидат технічних наук, доцент кафедри агроінженерії і технічного сервісу Вінницького національного аграрного університету (ВНАУ, вул. Сонячна, 3, м. Вінниця, Україна, 21008, e-mail: shlv0505@i.ua).

Середа Леонид Павлович - кандидат технических наук, професор кафедры агроинженерии и технического сервиса Винницкого национального аграрного университета (ВНАУ, ул. Солнечная, 3, г. Винница, Украина, 21008, e-mail: leonidsereda@vsau.vin.ua).

Труханская Елена Александровна - кандидат технических наук, доцент кафедры агроинженерии и технического сервиса Винницкого национального аграрного университета (ВНАУ, ул. Солнечная, 3, г. Винница, Украина, 21008, e-mail: seaswallow@ukr.net).

Швец Людмила Васильевна - кандидат технических наук, доцент кафедры агроинженерии и технического сервиса Винницкого национального аграрного университета (ВНАУ, ул. Солнечная, 3, г. Винница, Украина, 21008, e-mail: shlv0505@i.ua). 